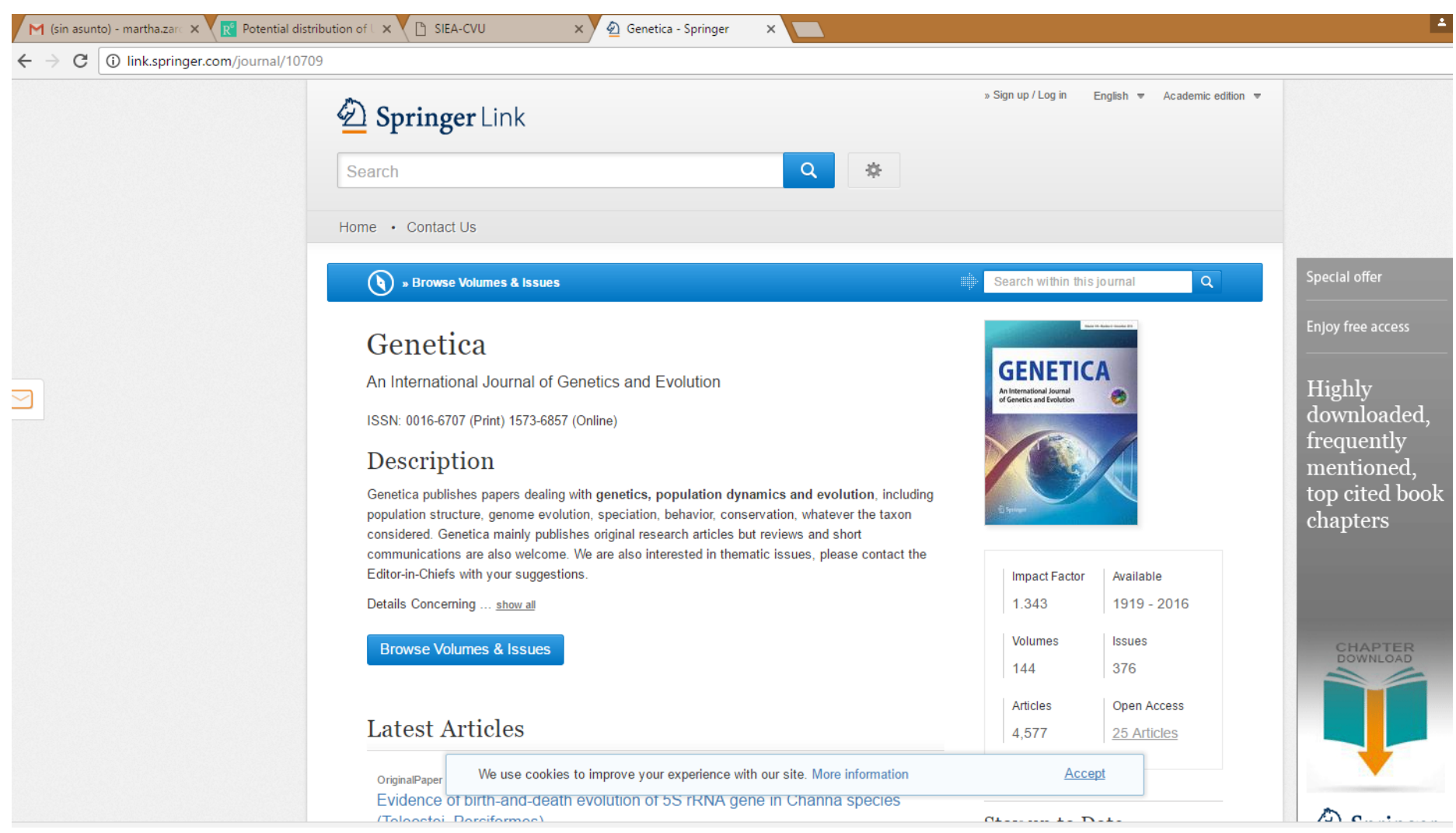


Genetios

All Volumes $\mathrm{B}$ lssues

\section{Volume 144, Issue 6, December 2016}

ISSN: 0016-6707 (Print) 1573-6857 (Onine)

In this issue ( 9 articles)

OriginalPaper

Genetic diversity and structure of Brazilian ginger germplasm (Zingiber officinale) revealed by AFLP markers

Eleonora Zambrano Blanco, Miklos Maximiliano Bajay...

* Download PDF (B71KB) D Vlew Article

Pages 627-638

Originaf Paper

ITS2 secondary structure for species circumscription: case study in southern African Strychnos L. (Loganiaceae)

Adekunle Adebowale, Jennifer Lamb, Ashley Nicholas, Yougasphree Naidoo

* Download PDF (1944KB) * Vlew Article

Pages 639-650

Origina/Paper

Genome wide association study (GWAS) for grain yield in rice cultivated under water deficit

Gabriel Feresin Pantalâo, Marcelo Narciso, Cléber Guimarães, Adriano Castro..

* Download PDF (844KB) D Vlew Article

Pages 651-664

BriafCommunication

Identification of critical amino acid residues and functional conservation of the Neurospora crassa and Rattus norvegicus orthologues of neuronal calcium sensor-1

Dibakar Gohain, Rekha Deka, Ranjan Tamuli

* Download PDF (954KB) D Vlew Arttcle

Pagอง 665-674

OriginalPaper

The complete mitochondrial genome of Trabala vishnou guttata (Lepidoptera: Lasiocampidae) and the related phylogenetic analyses Lisyu Wu, Xiao Xiong, Xuming Wang, Tianrong Xin, Jing Wang, Zhiwen Zou, Bin Xia

w Download PDF (1604KB) w Vlew Article

Pages 675-688

Originapaper

Genetic structure and diversity in an isolated population of an endemic mole salamander (Ambystoma rivulare Taylor, 1940) of central Mexico Rosa-Laura Heredia-Bobadilla, Octavio Monroy-Vilchis, Martha M. Zarco-González...

* Download PDF (767kB) D Vlew Article

Douniogd PDF (787


OriginalPaper

The complete mitogenome of a jumping spider Carrhotus xanthogramma

(Araneae: Salticidae) and comparative analysis in four salticid mitogenomes

Wen-Yuan Fang, Zheng-Liang Wang, Chao Li, Xiao-Qing Yang, Xiao-Ping Yu

* Download PDF (1540KB) "Vlew Article

Pages 699-709

OriginelPaper

Influence of environmental heterogeneity on the distribution and persistence of a subterranean rodent in a highly unstable landscape

María Jimena Gómez Fernández, Emma S. M. Boston, Oscar E. Gaggiotti...

* Download PDF (1193KB) „ Vlew Article

Pagea 711-722

OriginalPaper

Evidence of birth-and-death evolution of 5S rRNA gene in Channa species

(Teleostei, Perciformes)

Anindya Sundar Barman, Mamta Singh, Rajeev Kumar Singh, Kuldeep Kumar Lal

Pages 723-732 


\section{Genetic structure and diversity in an isolated population of an endemic mole salamander (Ambystoma rivulare...}

Article in Genetica · December 2016

DOI: $10.1007 /$ s10709-016-9935-9

CITATIONS

0

6 authors, including:

\section{Octavio Monroy-vilchis}

Universidad Autónoma del Estado de México 79 PUBLICATIONS 584 CITATIONS

SEE PROFILE

\section{Daniel Martinez}

Metropolitan Autonomous University 17 PUBLICATIONS 25 CITATIONS

SEE PROFILE

\section{Martha M Zarco-González}

Universidad Autónoma del Estado de México ... 29 PUBLICATIONS 257 CITATIONS

SEE PROFILE

\section{German D Mendoza}

Metropolitan Autonomous University 303 PUBLICATIONS 1,908 CITATIONS

SEE PROFILE

Some of the authors of this publication are also working on these related projects: 


\title{
Genetic structure and diversity in an isolated population of an endemic mole salamander (Ambystoma rivulare Taylor, 1940) of central Mexico
}

\author{
Rosa-Laura Heredia-Bobadilla ${ }^{1}$ - Octavio Monroy-Vilchis ${ }^{1}$. \\ Martha M. Zarco-González ${ }^{1}$ • Daniel Martínez-Gómez ${ }^{2}$ • \\ Germán David Mendoza-Martínez ${ }^{2} \cdot$ Armando Sunny $^{1}$
}

Received: 18 August 2016/Accepted: 18 October 2016/Published online: 28 October 2016

(c) Springer International Publishing Switzerland 2016

\begin{abstract}
Human activities are affecting the distribution of species worldwide by causing fragmentation and isolation of populations. Isolation and fragmentation lead to populations with lower genetic variability and an increased chance of inbreeding and genetic drift, which results in a loss of biological fitness over time. Studies of the genetic structure of small and isolated populations are critically important for management and conservation decisions. Ambystoma rivulare is a micro-endemic Mexican mole salamander from central Mexico. It is found in the most ecologically disturbed region in Mexico, the Trans-Mexican Volcanic Belt. The goal of this study of the population genetics of the micro-endemic mole salamander was to provide information to be used as a basis for future research and conservation planning of this species and other species of the Ambystoma genus in Mexico. The structural analysis found two subpopulations, one for each river sampled, with no signs of admixture and very high levels of genetic differentiation. Medium to high levels of heterozygosity and few alleles and genotypes were observed. Evidence of an ancestral genetic bottleneck, low
\end{abstract}

Electronic supplementary material The online version of this article (doi:10.1007/s10709-016-9935-9) contains supplementary material, which is available to authorized users.

Octavio Monroy-Vilchis

tavomonroyvilchis@gmail.com; omv@uaemex.mx

1 Centro de Investigación en Ciencias Biológicas Aplicadas, Universidad Autónoma del Estado de México, Instituto literario \# 100, Colonia Centro, CP 50000 Toluca, Estado de México, Mexico

2 Departamento de Producción Agrícola y Animal, Universidad Autónoma Metropolitana Xochimilco, Calz. Del Hueso 1100, Col. Villa Quietud, 04960 Mexico city, Mexico values of effective population size, small inbreeding coefficients, and low gene flow were also found.

Keywords Mole salamander - Conservation genetics · Micro-endemic species · Microsatellites · Conservation

\section{Introduction}

Biodiversity of the planet is rapidly decreasing as a consequence of human exploitation of land resources. Consequences of decreased biodiversity include reduced species richness (Waltert et al. 2004; Ribeiro et al. 2009), a decline in genetic diversity (Frankham et al. 2005), and changes in the distribution of fauna resulting from habitat loss (Ribeiro et al. 2009; Sarukhán et al. 2009). Loss of habitat can result in small, isolated, and fragmented populations. These populations tend to have an increased chance of inbreeding as well as less genetic variability due to a loss of alleles through genetic drift (Frankham et al. 2005; Sunny et al. 2014a; Rueda Zozaya et al. 2016), reducing their biological fitness over time (Lande 1988; Jehle and Arntzen 2002). In order to maintain sufficient levels of genetic variability for small, fragmented populations and ensure their long term survival, studies of genetic variability must be conducted so that management strategies can be improved (Frankham et al. 2005; Palsbøll et al. 2007; Bradshaw et al. 2010).

Mexico is a biodiverse country which ranks fifth in the number of amphibian species (Parra-Olea et al. 1999; FríasAlvarez et al. 2008) with 377 species (AmphibiaWeb 2016), of which 259 are endemic (Parra-Olea et al. 2014; FloresVillela and García-Vázquez 2014; AmphibiaWeb 2016). However, Mexico also ranks fourth in world deforestation rates (FAO 2006; Ellis and Porter-Bolland 2008), which increases fragmentation and isolation of wildlife populations. 
The Trans-Mexican Volcanic Belt (TMVB) is one of the most ecologically disturbed regions in the country due to its nearness to highly urbanized cities (Sunny et al. 2015). Mexico also has 18 Ambystoma species, of which 16 are endemic (Parra-Olea et al. 2014). Ambystoma rivulare is a micro-endemic mountain mole salamander that inhabits slow-flowing streams within the TMVB, surrounded by Pinus hartwegii and Abies religiosa forest. It is found in streams located above $2800 \mathrm{~m}$ above sea level (masl) (Barriga-Vallejo et al. 2015).

This species is endangered, along with most of the mole salamanders of Mexico (SEMARNAT 2010; Parra-Olea et al. 2012; Sunny et al. 2014a; IUCN 2016), largely due to deforestation, pollution of rivers, and the introduction of exotic species (Casas-Andreu et al. 2004; Beebee and Griffiths 2005; Zambrano et al. 2010). However, there is little information on the current population trend and the status of genetic variability of this species, except within the Special Reserve of the Monarch Butterfly (SRMB) (Parra-Olea et al. 2012). The IUCN categorizes this species as data deficient (Shaffer et al. 2008). Additionally, this species is found in one of the most fragmented and disturbed areas of Mexico, where the environment has been heavily impacted by agriculture and urban settlements. In fact, some of the largest metropolitan areas in Mexico are in the distribution range of $A$. rivulare (CONAPO 2010; Bryson et al. 2014; Sunny et al. 2015).

The aim of this study was to assess two small, fragmented populations of A. rivulare found in the Nevado de Toluca Volcano (NTV) natural protected area, part of the TMVB, by examining their genetic diversity and structure, level of inbreeding, current effective population size, and evidence for bottlenecks. The NTV was declared a natural protected area in 1936, but lack of communication between the government and communal land holders prevented proper implementation of protection laws. Consequently, the presence of human settlements, parks, trout farming, illegal logging and other human activities has continued to affect the biodiversity of this area (Candeau and Franco 2007). Based on this species' life history and the poor condition of the natural protected area, we expected to find low genetic variability, a high degree of genetic structure, small effective population sizes, and low gene flow in these populations. These results will provide valuable information for making management decisions to help preserve $A$. rivulare in the NTV.

\section{Materials and methods}

\section{Study site and population sampling}

Population sampling was conducted in the NTV $\left(18^{\circ}\right.$ $59^{\prime} \mathrm{N}$ ) in two small rivers surrounded by small alpine grassland, near a sacred fir and pine forest (Abies religiosa and Pinus hartwegii), at an altitude of 3200 masl. The sampling site is a recreational park with ecotourism activities, trout farming, and cattle and sheep grazing (Fig. 1). Tissue samples from 54 individuals were collected in the first river, and from 32 individuals in the second river. In order to represent all maturity stages of $A$. rivulare in the data, tissue was obtained from both adults and larvae. Sampling of larvae was limited $(>10 \%)$ and efforts were made to avoid sampling siblings. A total of 14 sampling sites were chosen after considering the characteristics of different micro-environments presented by the rivers (presence of ponds, flow rates, substrate type, amount of vegetation, etc.). Individuals were captured with a fishing net and a $2 \mathrm{~mm}^{2}$ tail clip was collected. This methodology is low-impact and does not affect the survival or growth of the mole salamanders (Arntzen et al. 1999; Polich et al. 2013). Tissue samples were preserved in $90 \%$ ethanol and then frozen at $-20{ }^{\circ} \mathrm{C}$ until processing could be completed. All mole salamanders were released immediately at the point of capture.

\section{DNA extraction and microsatellite amplification}

DNA extraction was performed with a commercial kit (Vivantis GF-1 Tissue DNA extraction kit). Genomic DNA was used as a template for amplification of nine microsatellite loci: At 52.2, At 52.10, At 52.143, At 60.3, At 52.115, At 52.6, At 52.34, At 52.20, and At 52.1 (ParraOlea et al. 2007). PCR reactions were performed in a Techne thermocycler. Amplified products were multiplexed on an ABI Prism3730xl and sized in PEAK SCANNER V1.0 (Applied Biosystems 2006) software using ROX-500 as an internal size standard. Allele sizes were measured and binned with the software TANDEM (Matschiner and Salzburger 2009).

\section{Microsatellite analysis}

\section{Potential scoring errors and genetic structure}

The presence of null alleles and other genotyping errors was determined using the software MICROCHECKER (Van Oosterhout et al. 2004).

We used the software STRUCTURE 2.3.4 (Pritchard et al. 2000) to infer the population structure. Due to the lack of genetic structure found in previous studies, the results of exploratory analyses of these data $(K=10$, $\mathrm{K}=8, \mathrm{~K}=5, \mathrm{~K}=3, \mathrm{~K}=2$ and $\mathrm{K}=1$; results not shown), and the results of a Delta $K(\Delta K)$ Evanno plot (see results), we decided to explore values of $\mathrm{K}$ from 1 to 8 . The analysis was run ten times per $\mathrm{K}$ value in order to determine the maximum value of posterior likelihood $[\ln P(D)]$. 


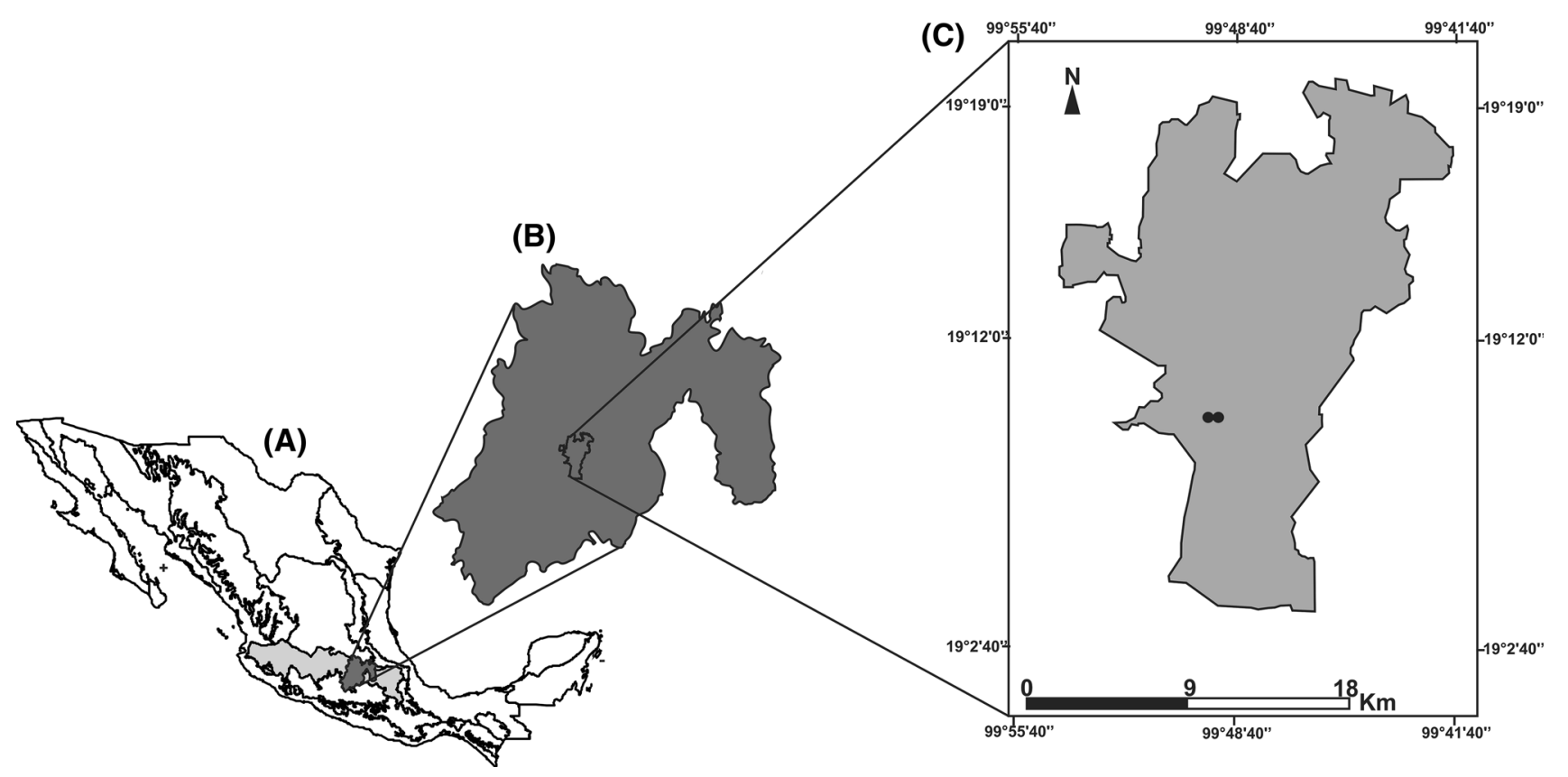

Fig. 1 a Map of Mexico showing the Trans-Mexican Volcanic Belt in light gray and in dark grey the State of Mexico. b State of Mexico, c Raíces, Zinacantepec, the black dots are the study sites

For each analysis we used 100,000 Markov chains following a burn-in period of 50,000 chains (Espindola et al. 2014).

A Dirichlet parameter was used to assess the degree of admixture; allele frequencies in each genetic group were correlated with the allele frequencies of an ancestral population, without prior information on population origin. We used the software STRUCTURE HARVESTER 0.6.92 (Earl and vonHoldt 2011) to determine the most probable number of clusters to best represent our data. Following the method of Evanno et al. (2005), we searched for the maximum value of $\Delta \mathrm{K}$ (i.e. the ad hoc quantity related to the second order rate of change of the $\log$ probability of data) with respect to the number of clusters. We also used the software GENELAND 3.2.2 (Guillot et al. 2005) to infer population structure. GENELAND 3.2.2. implements a Bayesian algorithm through a Markov chain Monte Carlo procedure using genetic data and geographical coordinates. The program was run using the assumptions of a correlated allelic frequencies model and true spatial model (Guillot et al. 2005). We performed 10 independent runs of $1,000,000$ iterations (thinning $=100, \quad$ burn-in $=1000$ ) using $\mathrm{K}=10, \mathrm{~K}=5, \mathrm{~K}=3, \mathrm{~K}=2$, and $\mathrm{K}=1$ (VázquezDomínguez et al. 2012; Sunny et al. 2014a). Finally, we used an analysis of molecular variance (AMOVA) to analyze the distribution of the genetic variance between and within populations, based on $\mathrm{F}_{\mathrm{ST}}$ values, with 10,000 permutations in the program ARLEQUIN 3.5.1.2 (Excoffier and Lischer 2010).

\section{Genetic diversity}

Linkage disequilibrium (LD) between all pairs of loci across all populations and conformance to Hardy-Weinberg equilibrium (HWE) expectations was evaluated using GENEPOP 4.2 (Raymond and Rousset 1995), which conducts exact tests $(10,000$ dememorization steps, 1000 batches and 10,000 iterations). A false discovery rate (FDR) test was performed using R 2.8.1 Q-VALUE (R Development Core Team 2013) in order to analyze the significance of data obtained. With GENALEX (Peakall and Smouse 2006), we estimated the observed (Na) and effective number $(\mathrm{Ne})$ of alleles per locus as well as the observed $\left(\mathrm{H}_{\mathrm{o}}\right)$ and expected heterozygosity $\left(\mathrm{H}_{\mathrm{e}}\right)$. FSTAT 2.9.3.2 (Goudet 2002) software was used to obtain an estimate of allelic richness (A). In addition, we used SMOGD 1.2.5 (Crawford 2010) software, with 1000 bootstrap replications for each parameter, to calculate several estimators of genetic population differentiation such as $\mathrm{G}_{\mathrm{ST} \_ \text {est }}(\mathrm{Nei}$ et al. 1983), G'ST_est $\left(\right.$ Hedrick 2005; Jost 2008), $\Delta_{\text {ST }}$, D, and $D_{\text {est }}$ (Jost 2008). We estimated Nei's genetic distance (Nei 1972) between sampling locations with GENALEX.

\section{Gene flow, effective population size, inbreeding and bottlenecks}

The gene flow was estimated with MIGRATE-N 3.6 (Beerli 2008), which utilizes Bayesian inferences. The Brownian motion model was used and we conducted five independent runs of four long chains of 10,000,000 genealogies, sampled 
every 1000 steps, and a burn-in of 1,000,000 steps. The four heated chains had temperatures: $\mathrm{T} 1=1.0, \mathrm{~T} 2=1.5$, $\mathrm{T} 3=3.0$ and $\mathrm{T} 4=1,000,000$. Default values were applied for the remaining parameters; effective immigration $(\mathrm{M})$ rate and effective population size $(\Theta)$ were obtained.

To estimate the number of migrants per generation $\left(\mathrm{N}_{\mathrm{em}}\right)$, we used the two populations defined by the STRUCTURE analysis $M$ was multiplied by $\Theta$ (Beerli 2009, 2012). The effective population size (Ne) was determined by examining LD in the software NE ESTIMATOR 2.01 (Do et al. 2014). As an inbreeding measure, we used the relatedness estimator $\left(\mathrm{r}_{\mathrm{qg}}\right)$ of Queller and Goodnigh (1989), calculated by the software GENALEX. To test for significant differences among mean population relatedness, we calculated the upper and lower $95 \%$ confidence intervals for the expected range of $r_{\mathrm{qg}}$ using 9999 permutations. These intervals correspond to the range of $r_{\mathrm{qg}}$ that would be expected if reproduction were random across the populations. Also, we calculated confidence intervals for estimates of mean relatedness within a population to $95 \%$ by bootstrap resampling (9999 permutations). Population $\mathrm{r}_{\mathrm{qg}}$ values that fall above the $95 \%$ expected values indicate that processes such as inbreeding or genetic drift are increasing relatedness. Finally, we used the coefficient of inbreeding ( $\left.\mathrm{F}_{\mathrm{IS}}\right)$, calculated by GENEALEX, as an indicator of total inbreeding in the population.

We used the software BOTTLENECK 1.2.02 (Cournet and Luikart 1996; Piry et al. 1999) to search for evidence of genetic bottlenecks events. We estimated the observed and expected heterozygosity under the infinite allele model (IAM), stepwise mutation model (SMM), and the two-phase model (TPM) with settings at $90 \%$ SMM, $10 \%$ IAM, and $10 \%$ variance and also using the default values (70 \% SMM, $30 \%$ IAM, and $10 \%$ variance). Both parameter settings were run with 10,000 replicates. Excess heterozygosity was tested with a Wilcoxon test. Finally, historical bottlenecks were tested with the Garza-Williamson (M) index, which was calculated with ARLEQUIN 3.5.1.2 software (Excoffier and Lischer 2010) and with CRITICAL M software (Garza and Williamson 2001). A critical $\mathrm{M}\left(\mathrm{M}_{\mathrm{c}}\right)$ value was obtained using 10,000 simulations and parameters from the two-phase mutation model, as described in Garza and Williamson (2001). M-values lower than the critical number, are indicative of historical population declines (Cournet and Luikart 1996; Garza and Williamson 2001).

\section{Results}

\section{Potential scoring errors and genetic structure}

Null alleles and other genotyping errors were not detected at any loci.
The highest log likelihood given by STRUCTURE was observed when $\mathrm{K}=2(\operatorname{LnPr}=-1769.7)$; the $\Delta \mathrm{K}$ method also chose two populations as the best model (Fig. 2). With GENELAND, three subpopulations were defined $(\operatorname{LnPr}=-2705.93)$. Since STRUCTURE assigned almost every individual to the river where it was collected, and the maximum value of $\Delta \mathrm{K}$ (Evanno et al. 2005) analysis also suggested the presence of two subpopulations, we performed posterior analysis with two subpopulations. Population sampling was done in two independent streams, so using two subpopulations for analysis seemed to accurately represent the structure of $A$. rivulare at this study site. We defined these populations as Stream $1(\mathrm{SUBP} 1: \mathrm{N}=54)$ and Stream 2 (SUBP2: $\mathrm{N}=32$ ). Other genetic structure analysis showed low genetic structure between the two populations $\quad\left(\mathrm{F}_{\mathrm{ST}}=0.076, \quad \mathrm{G}_{\mathrm{ST} \_ \text {est }}=0.068, \quad \mathrm{G}_{\mathrm{ST}_{\mathrm{S}} \text { est }}=\right.$ $0.300, \Delta_{\mathrm{ST}}=1.258, \mathrm{D}=0.299, \quad \mathrm{D}_{\mathrm{est}}=0.285, \mathrm{~N}_{\mathrm{ei}}{ }^{\prime} \mathrm{s}=$ 0.328 ; Table 1 and 2). The $\mathrm{F}_{\mathrm{ST}}$ calculated by AMOVA $\left(\mathrm{F}_{\mathrm{ST}}=0.076\right)$ revealed that most of the genetic diversity is attributed to variation among populations (72\%; $p=0.000)$, and only a small amount $(21 \% ; p=0.000)$ occurs among individuals or within populations.

\section{Genetic variability}

FDR correction found departures from HWE at loci At 52.10 and At 52.115 because of a heterozygote deficit $\left(\mathrm{F}_{\mathrm{IS}}=-0.340\right)$. Linkage disequilibrium was not detected at any loci. Across the nine loci in the two populations, 68 alleles were identified, with a range of 2-7 (average 3.778) alleles per locus. SUBP1 had a total of 38 alleles, with 2-6 alleles per locus (mean $=4.222$ ). SUBP2 had 2-5 alleles per locus (mean $=3.333$ ) and a total of 30 alleles (Table 1; Fig. A2). Between the two populations, 91 genotypes were found (Table A3). There was a range of 2-10 (average 6.222) genotypes per locus for SUBP1 and 2-7 (average of 3.888) for SUBP2. Twenty-nine heterozygous genotypes and 27 homozygous genotypes were found in SUBP1, with a total of 56 genotypes. SUBP2 had a total of 35 genotypes, 18 heterozygous and 17 homozygous. SUBP1 showed lower observed and expected heterozygosity values $\left(\mathrm{H}_{\mathrm{o}}=0.761, \mathrm{H}_{\mathrm{e}}=0.622\right)$ as compared to SUBP2 $(\mathrm{Ho}=0.837, \mathrm{He}=0.591$; Table 1$)$.

\section{Gene flow, effective population size, relatedness and bottlenecks}

With regard to gene flow, the MIGRATE-N estimates of $\Theta$ for the two populations were 0.00273 for SUBP1 and 0.00412 for SUBP2. Migration rates per generation from SUBP1 to SUBP2 were 1.08 and from SUBP2 to SUBP1 were 0.137 . With an allelic frequency of 0.05 , the $\mathrm{Ne}$ in the 

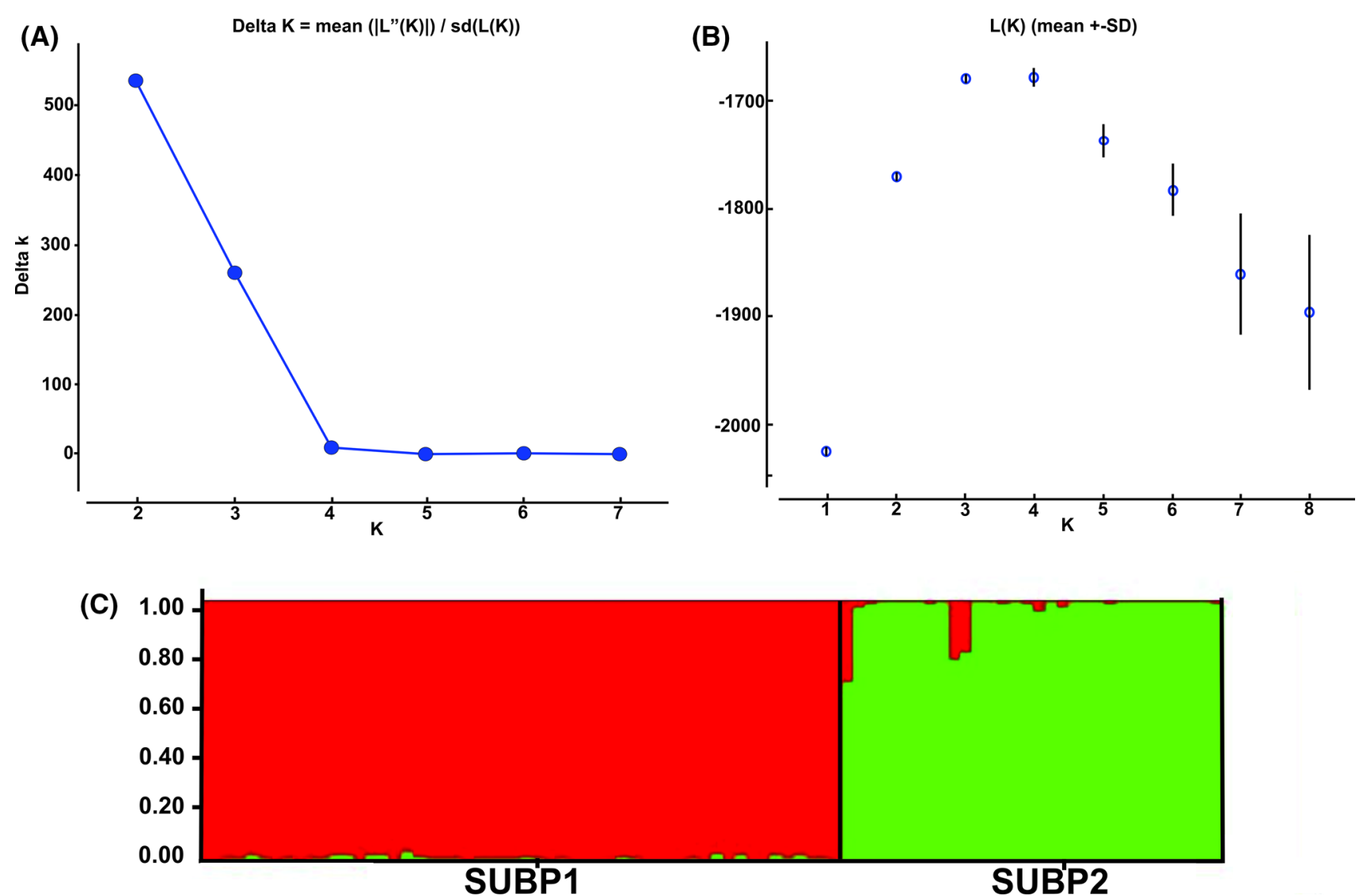

Fig. 2 Ambystoma rivulare genetic structure: $\mathbf{a}, \mathbf{b} \Delta \mathrm{K}$ value of Evanno et al. (2005) plots for detecting the number of $\mathrm{K}$ groups that best fit the data. c Population genetic structure partitioned into $\mathrm{K}$ components representing the ancestry fractions in $\operatorname{LnPr}(\mathrm{K}=2)=-1769.7$ populations

Table 1 A. rivulare genetic diversity values in the SUBP1 and in the SUBP2 populations

\begin{tabular}{llllrlll}
\hline & $\mathrm{N}$ & $\mathrm{Na}$ & $\mathrm{Ne}$ & $\mathrm{Np}$ & $\mathrm{Ho}$ & $\mathrm{He}$ & \multicolumn{1}{l}{$\mathrm{F}_{\text {IS }}$} \\
\hline SUBP1 & 54 & 4.222 & 4.222 & 15 & 0.761 & 0.622 & -0.225 \\
SUBP2 & 32 & 3.333 & 3.333 & 7 & 0.837 & 0.561 & -0.512 \\
Total mean & & 3.778 & 2.605 & 11 & 0.799 & 0.591 & -0.360 \\
\hline
\end{tabular}

$N$ sample size, $N a$ number of alleles, $N e$ number of effective alleles, $N_{p}$ number of private alleles, $H_{o}$ observed heterozygosity, $H_{e}$ expected heterozygosity, $F_{I S}$ fixation index

LD model was 19.9 for SUBP2 and 7.7 for SUBP2. The $F_{I T}$ statistic for the whole population, used as an indicator of inbreeding, showed low inbreeding values $\left(\mathrm{F}_{\mathrm{IT}}=-0.248\right.$; Table 2). We found that mean pairwise relatedness $\left(\mathrm{r}_{\mathrm{qg}}\right)$ within populations (Fig. 3) was generally in accordance with that observed in other Ambystoma populations (ParraOlea et al. 2012; Sunny et al. 2014a; Percino-Daniel et al. 2016). The SUBP1 population had low values of inbreeding (mean $\mathrm{r}_{\mathrm{qg}}=0.098$, confidence interval $(\mathrm{CI})=0.022-0.039)$ and SUBP2 had medium to high values (mean $\mathrm{r}_{\mathrm{qg}}=0.445, \quad \mathrm{CI}=0.048-0.058$ ). The
BOTTLENECK analysis did not detect any signs of the recent and/or sharp demographic changes which are typical of bottleneck events. However, critical $\mathrm{M}\left(\mathrm{M}_{\mathrm{c}}\right)$ values were significantly higher (SUBP1: $\mathrm{M}_{\mathrm{c}}=1.5$ and SUBP2: $\mathrm{M}_{\mathrm{c}}=1.05$ ) than $\mathrm{M}$ values (SUBP1 $\mathrm{M}=0.47534$ and SUBP2 $M=0.36772$ ) in both subpopulations, indicating historical reductions in effective population size or historical bottlenecks.

\section{Discussion}

This is the first population genetics study of A. rivulare in the NTV. This species is very sensitive to environmental changes such as pollution of streams. Anthropogenic activities have already caused the loss of approximately $50 \%$ of amphibian diversity worldwide (Marsh and Trenham 2001; Storfer et al. 2009).

\section{Genetic structure}

Our genetic structure analysis found two subpopulations, one for each river sampled, with no signs of admixture and 
Table 2 A. rivulare measures of genetic differentiation for the populations and for each locus

\begin{tabular}{lllllrllr}
\hline Locus & F IS & \multicolumn{1}{l}{$\mathrm{F}_{\mathrm{IT}}$} & $\mathrm{F}_{\mathrm{ST}}$ & GST_est & $\mathrm{G}_{\text {'ST_est }}$ & $\Delta_{\text {ST }}$ & $\mathrm{D}$ & $\mathrm{D}_{\text {est }}$ \\
\hline At 52.2 & -0.586 & -0.524 & 0.039 & 0.033 & 0.084 & 1.032 & 0.062 & 0.053 \\
At 52.10 & -0.402 & -0.064 & 0.241 & 0.229 & 1.000 & 2.000 & 1.000 & 1.000 \\
At 52.143 & -0.354 & -0.164 & 0.140 & 0.134 & 0.593 & 1.370 & 0.540 & 0.530 \\
At 60.3 & -0.314 & -0.310 & 0.003 & -0.003 & -0.015 & 1.006 & 0.011 & -0.012 \\
At 52.115 & -0.199 & -0.191 & 0.007 & 0.002 & 0.009 & 1.014 & 0.028 & 0.007 \\
At 52.6 & -0.209 & -0.209 & 0.000 & -0.006 & -0.017 & 1.000 & 0 & -0.011 \\
At 52.34 & -0.500 & -0.181 & 0.212 & 0.202 & 0.919 & 1.820 & 0.901 & 0.899 \\
At 52.20 & -0.216 & -0.200 & 0.013 & 0.005 & 0.031 & 1.028 & 0.054 & 0.026 \\
At 52.1 & -0.431 & -0.387 & 0.031 & 0.018 & 0.092 & 1.051 & 0.097 & 0.074 \\
Mean & -0.360 & -0.248 & 0.076 & 0.068 & 0.300 & 1.258 & 0.299 & 0.285 \\
\hline
\end{tabular}

$\mathrm{F}_{\mathrm{IS}}, \mathrm{F}_{\mathrm{ST}}$ and $\mathrm{F}_{\mathrm{IT}}$ - fixation indices estimated according to Weir and Cockerham (1984), G $\mathrm{G}_{\mathrm{ST} \text { est }}$-nearly

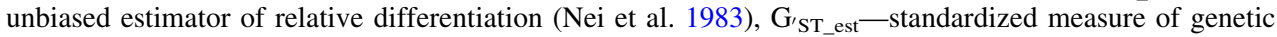
differentiation (Hedrick 2005), $\Delta_{\mathrm{ST}}$-between-subpopulation component of diversity or the effective number of distinct subpopulations, $\mathrm{D}$ - actual differentiation and $\mathrm{D}_{\text {est }}$ - estimator of actual differentiation (Jost 2008)

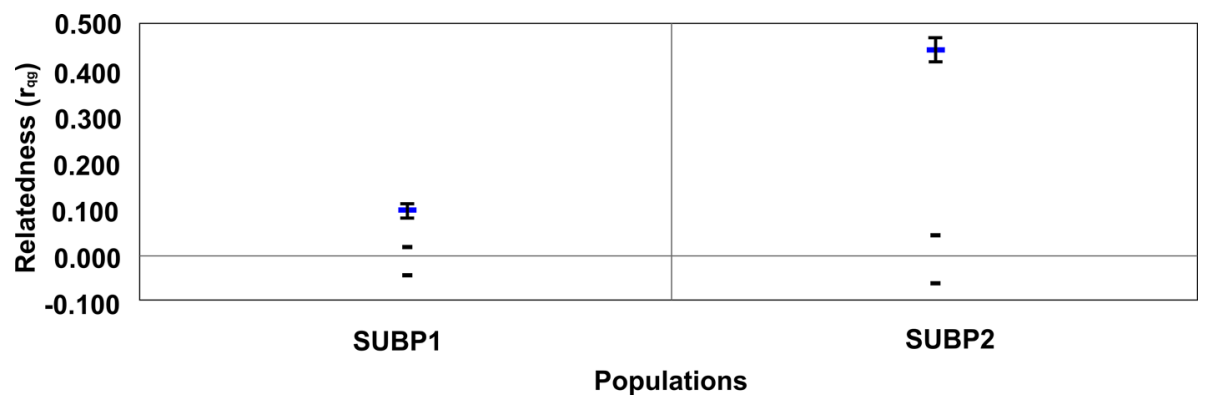

Fig. 3 Mean within-populations pairwise relatedness coefficient $r_{\mathrm{qg}}$ across the Ambystoma populations studied. The black bars are $95 \%$ upper and lower expected values for a null distribution generated from 999 permutations of data from all populations, and enclose the values expected if breeding were panmictic across the populations;

a very high level of genetic differentiation. This is a trend which commonly occurs in mole salamanders (Savage et al. 2010; Parra-Olea et al. 2012; Sunny et al. 2014a, b) residing at high elevations. Mountain habitats are associated with severe topographical, climatic, and ecological conditions (Savage et al. 2010). The sampled rivers stem from different tributaries, are separated by low vegetation cover, and experience low air and water temperatures with different durations and intensities. Cows and sheep graze near these streams and other human activities such as tourism, horseback riding, and mountain biking take place in the area. All of these factors can significantly limit gene flow between populations (Naughton et al. 2000; Wang et al. 2009; Johnson et al. 2010; Savage et al. 2010; Sunny et al. 2014a) leading to high levels of genetic structure (Funk and Dunlap 1999; Tallmon et al. 2000). The biological and life history features that characterize amphibians in general, like the fine genetic structure over very short distances (Savage et al. 2010; Sunny et al. 2014a, b) resulting from female philopatry (Savage et al. 2010; Wang relatedness in the two populations fell outside of the range expected under panmixia. Blue bars represent the observed mean relatedness in each population or species, with the upper and lower bootstrap value for each population

and Summers 2010; Pauly et al. 2012) and low dispersal ability (Trenham and Shaffer 2005; Gamble et al. 2006, 2007; Searcy and Shaffer 2008; Summitt 2009; Savage et al. 2010; Sunny et al. 2014a; Percino-Daniel et al. 2016), favor the genetic structure observed. In fact, $A$. rivulare is a species which, even after metamorphosis, consistently remains in the same river (Shaffer et al. 2008).

\section{Genetic variability}

Two loci (At 52.10 and At 52.115) showed significant deviation from HWE because of a heterozygote deficiency. These deviations are common in threatened species with fragmented and isolated populations (Degne et al. 2007; Spear and Storfer 2010; Parra-Olea et al. 2012; Sunny et al. 2014a, 2015; Percino-Daniel et al. 2016). Analyses showed low levels of inbreeding and no presence of null alleles. It is also unlikely that a Wahlund effect is acting, since the two subpopulations were analyzed separately. So, the observed deviation from HWE could be the result of 
genetic drift (Hedrick 2005). Genetic drift is considered to be the main cause of long-term loss of genetic variation and it leads to an increased chance of inbreeding, the foremost genetic factor threatening short-term survival of populations (Frankham et al. 2005; Vega et al. 2007; Sunny et al. 2014b)

The genetic variability found in this study was slightly higher than the figure reported for $A$. rivulare from the SRMB (Parra-Olea et al. 2012). This may be due to the constant anthropogenic pressures occurring in the SRMB (Vidal et al. 2014), where there are high rates of logging, agriculture, livestock production, fires, and ecotourism activities, despite its status as a natural reserve (WWF 2004; Champo-Jiménez et al. 2012). Over the course of four months, 87,337 people, from Mexico and around the world, visited the SRMB (Vidal et al. 2014). In the NTV, local people are leading the movement for implementation of improved conservation strategies for the forest and also for $A$. rivulare populations. This site is used for ecotourism activities, which benefit the local people, so by conserving the forest and the Ambystomas they ensure continuation of their income.

Despite the presence of anthropogenic pressures, and contrary to our expectations, the Ho values obtained for these populations were higher than those found for most of the other mole salamander species in Mexico (Parra-Olea et al. 2012; Percino-Daniel et al. 2016) and were similar to values observed in species that have been demographically stable (Goprenko et al. 2007; Dlugosh and Parker 2008; Greenwald et al. 2009; Purrenhage et al. 2009; Wang et al. 2009). However, the average number of alleles in these populations was very low. This is important to note because the genetic diversity of this species could be starting to decline due to habitat fragmentation, anthropogenic activities, and isolation (Noël and Lapointe 2010). Unfortunately, it is also very likely that the amount of logging and other human land use will increase in the near future because the government has recently changed the protection status of the NTV (DOF 2013; Mastretta-Yanes et al. 2014).

\section{Gene flow, effective population size, inbreeding and bottlenecks}

We found little evidence of gene flow, just one migrant per generation from SUBP1 to SUBP2. This is a common trend in mole salamander populations, especially in high mountain populations (Savage et al. 2010; Parra-Olea et al. 2012; Sunny et al. 2014a). This trend is likely the result of intrinsic biological characteristics of the species such as its limited dispersive capacity and highly philopatric tendencies (Savage et al. 2010). Some studies concluded that a minimum of one migrant per generation is sufficient to avoid the effects of consanguinity, but in small and fluctuating populations, 3-10 migrants per generation are necessary to prevent inbreeding (Vucetich and Waite 2000). Given the levels of gene flow observed, these subpopulations could be in process of inbreeding. Low gene flow and the onset of inbreeding could contribute to the low number of alleles found in the subpopulations and the low values of $\mathrm{Ne}$ obtained. Other factors such as bottlenecks, genetic isolation, asymmetry in the proportions of males and females, and differences in reproductive success between individuals may also be involved in generating low Ne values (Tennessen and Zamudio 2003; Myers and Zamudio 2004; Semlitsch 2008; Wang 2009).

Mole salamanders typically have low Ne values (Spear et al. 2006; Wang 2009; Savage et al. 2010; Parra-Olea et al. 2012, Sunny et al. 2014a; Percino-Daniel et al. 2016) resulting from high asymmetry in reproductive success among the members of a population (Savage et al. 2010). If only a few individuals successfully breed each year, the variance in mating success may contribute strongly to low overall effective population sizes (Savage et al. 2010). We found low to moderate levels of inbreeding, possibly because we collected most of the individuals between March and August, when largely gilled larva and eggs are found (Sunny et al. 2014b; Monroy-Vilchis et al. 2015; Lemos-Espinal et al. 2016). The $\mathrm{r}_{\mathrm{qg}}$ values observed in this study fell above the $95 \%$ intervals for the expected values, which indicates that inbreeding or genetic drift are increasing the relatedness. The $\mathrm{r}_{\mathrm{qg}}$ values found in the two subpopulations fell outside of the range expected under panmixia,, another possible explanation for the low $\mathrm{Ne}$ found. The inbreeding values of SUBP2 are very similar that those found in the $A$. rivulare population in the SRMB (Parra-Olea et al. 2012). Given the population history, lineage effects, and the environmental conditions encountered by the populations in this study, the amount of inbreeding is surprisingly low (Keller and Waller 2002; Parra-Olea et al. 2012).

Finally, we did not find evidence for a recent genetic bottleneck, perhaps indicating that the conservation plans currently being implemented by the local people are effective. However, we found signatures of ancestral genetic bottlenecks, possibly associated with a founder effect suffered when theses populations were separated from a larger ancestral population.

\section{Conservation implications}

All of the Ambystoma species of the TMVB (including $A$. rivulare, A. altamirani, A. leorae, A. mexicanum, A. granulosum, A. andersoni, $A$. velasci and A. lermaense) are threatened by habitat loss, fragmentation, and contamination of rivers and lakes. Amphibians are extremely 
sensitive to local habitat changes (Castellano and Valone 2006; Ribeiro et al. 2009), more so than other vertebrate taxa (White et al. 1997; Ribeiro et al. 2009), because of their low dispersal capacities and small home ranges (Huey 1982). Therefore, to maintain populations of A. rivulare, it is necessary to implement informed conservation strategies to preserve the highly endangered habitat of this species. The NTV is a high mountain region of the TMVB, the most disturbed region in Mexico, with only $1346.9 \mathrm{~km}^{2}(1.1 \%)$ of Abies forest and $6507.7 \mathrm{~km}^{2}(5.4 \%)$ of Pinus forest remaining (Sunny et al. 2015). Most of the streams are contaminated and overexploited, a condition which has put most of the Ambystoma species in Mexico in a threatened situation. This study shows that the current conservation efforts being enacted by the local people are working, but, in order to improve protection of this species, it is necessary to communicate information to the local people. The genetic structure information from this study can be used as a basis for future research and conservation planning for the Ambystoma Genus. Furthermore, A. rivulare may be used as a proxy for other amphibian species in the region.

Acknowledgements The Universidad Autónoma del Estado de México funded the study (3047-2011E). R.L.H-B is grateful to CONACYT and COMECYT (359990 and 16BTID0028) for scholarships. To the students of CICBA for helps us in data collect. We also thank the editor and two anonymous reviewers for their comments.

\section{References}

AmphibiaWeb (2016) Information on amphibian biology and conservation. AmphibiaWeb, Berkeley. http://amphibiaweb.org/. Accessed 20 Jan 2016

Arntzen JW, Smithson A, Oldham RS (1999) Marking and tissue sampling effects on body condition and survival in the newt Triturus cristatus. J Herpetol 33(4):567-576

Barriga-Vallejo C, Hernández-Gallegos O, Von-Herbing IH, LópezMoreno AE, Ruiz-Gómez ML, Granados-González G, GarduñoPaz MV, Méndez-Sánchez JF, Banda-Leal J, Davis AK (2015) Assessing population health of the Toluca Axolotl Ambystoma rivulare (Taylor, 1940) from México using leukocyte profiles. Herpetol Conserv Biol 10(2):592-601

Beebee TJ, Griffiths RA (2005) The amphibian decline crisis: a watershed for conservation biology? Biol Conserv 125(3):271-285

Beerli P (2008) Migrate version 3.0: a maximum likelihood and Bayesian estimator of gene flow using the coalescent. http:// popgen.sc.fsu.edu/Migrate/Migrate-n. Accessed 13 Nov 2014

Beerli P (2009) How to use migrate or why are Markov chain Monte Carlo programs difficult to use? In: Bertorelle G, Bruford MW, Hauffe HC, Rizzoli A, Vernesi C (eds) Population genetics for animal conservation: volume 17 of conservation biology. Cambridge University Press, Cambridge, pp 42-79

Beerli P (2012) Migrate documentation. http://popgen.sc.fsu.edu/ migratedoc.pdf. Accessed 17 Aug 2015

Bradshaw CJA, Brook BW, Whiteman NK (2010) The conservation biologist's toolbox-principles for the design and analysis of conservation studies. In: Sodhi NJ, Ehrlich PR (eds)
Conservation biology for all. Oxford University Press, Great Britain, pp 330-333

Bryson RW, Linkem CW, Dorcas ME, Lathrop A, Jones JM, Alvarado-Díaz J, Grünwald CI, Murphy RW (2014) Multilocus species delimitation in the Crotalus triseriatus species group (Serpentes: Viperidae: Crotalinae) with the description of two new species. Zootaxa 3:475-496

Candeau DR, Franco MS (2007) Dinámica y condiciones de vida de la población del Parque Naciona Nevado de Toluca (PNNT) en la generación de presión a los sistemas circundantes. Investig Geogr 62:44-68

Casas-Andreu G, Cruz-Aviña R, Aguilar-Miguel X (2004) Un regalo poco conocido de México al mundo: el ajolote o axolotl (Ambystoma: Caudata: Amphibia) con algunas notas sobre la crítica situación de sus poblaciones. Cienc Ergo Sum 10(3):304-308

Castellano MJ, Valone TJ (2006) Effects of livestock removal and perennial grass recovery on the lizards of a desertified arid grassland. J Arid Environ 66:87-95

Champo-Jiménez O, Valderrama-Landeros L, España-Boqueros ML (2012) Forest cover loss in the Monarch Butterfly biosphere reserve, Michoacán, México (2006-2010). Rev Chapingo 18(2):143-157

CONAPO (2010) Delimitación de las zonas metropolitanas de México. http://www.conapo.gob.mx/en/CONAPO/Zonas_metro politanas_2010. June 20th, 2016

Cournet JM, Luikart G (1996) Description and power analysis of two tests for detecting recent populations bottleneck from allele frequency data. Genetics 144:2001-2014

Crawford NG (2010) SMOGD: software for the measurement of genetic diversity. Mol Ecol Resour 10:556-557

Degne JF, Stout IJ, Roth JD, Parkinson CL (2007) Population genetics and conservation of the threatened southeastern beach mouse (Peromyscus polionotus niveiventris): subspecies and evolutionary units. Conserv Genet 8:1441-1452

Diario Oficial de la Federación Mexicana (DOF) (2013) DECRETO que reforma, deroga y adiciona diversas disposiciones del diverso publicado el 25 de enero de 1936, por el que se declaró Parque Nacional la montaña denominada "Nevado de Toluca" que fue modificado por el diverso publicado el 19 de febrero de 1937. México

Dlugosh KM, Parker M (2008) Founding events in species invasions: genetic variation adaptive evolution and the role of multiple introductions. Mol Ecol 17:431-449

Do C, Waples RS, Peel D, Macbeth GM, Tillett BJ, Ovenden JR (2014) NeEstimator 2: re-implementation of software for the estimation of contemporary effective population size $(\mathrm{Ne})$ from genetic data. Mol Ecol Resour 14:209-214

Earl DA, vonHoldt BM (2011) STRUCTURE HARVESTER: a website and program for visualizing STRUCTURE output and implementing the Evanno method. Conserv Genet Resour 4:359-361

Ellis EA, Porter-Bolland L (2008) Is community-based forest management more effective than protected areas?: a comparison of land use/land cover change in two neighboring study areas of the Central Yucatan Peninsula, Mexico. Forest Ecol Manag 256(11):1971-1983

Espindola S, Cuarón AD, Gaggiotti OE, Vázquez-Domínguez E (2014) High genetic structure of the Cozumel Harvest mice, a critically endangered island endemic: conservation implications. Conserv Genet 15:1393-1402

Evanno G, Regnaut S, Goudet J (2005) Detecting the number of clusters of individuals using the software STRUCTURE: a simulation study. Mol Ecol 14:2611-2620 
Excoffier L, Lischer HEL (2010) Arlequin suite ver 3.5: a new series of programs to perform population genetics analyses under Linux and Windows. Mol Ecol Resour 10:564-567

FAO Statistics database (2006). http://faostat.fao.org/. Accessed 10 June 2016

Flores-Villela O, García-Vázquez UO (2014) Biodiversidad de reptiles en México. Rev Mex Biodivers 85:467-475

Frankham R, Ballou J, Briscoe D (2005) Introduction to conservation genetics. Cambridge University Press, Cambridge

Frías-Alvarez P, Vance TV, Familiar-López M, Longocore JE, González-Bernal E, Santos-Barrera G, Zambrano L, Parra-Olea G (2008) Chytridiomycosis survey in wild and captive Mexican amphibians. Eco Health 5:18-26

Funk WC, Dunlap WW (1999) Colonization of high-elevation lakes by long-toed salamanders (Ambystoma macrodactylum) after the extinction of introduced trout populations. Can J Zool 77:1759-1767

Gamble LR, McGarigal K, Jenkins CL, Timm BC (2006) Limitations of regulated "buffer zones" for the conservation of marbled salamanders. Wetlands 26:298-306

Gamble LR, McGarigal K, Compton BW (2007) Fidelity and dispersal in the pond-breeding amphibian Ambystoma opacum: implications for spatio-temporal population dynamics and conservation. Biol Conserv 139:247-257

Garza JC, Williamson EG (2001) Detection of reduction in population size using data from microsatellite loci. Mol Ecol 10:305-318

Goprenko D, Williams RN, DeWoody JA (2007) Reproductive and mating success in the small-mouthed salamander (Ambystoma texanum) estimated via microsatellite parentage analysis. Evol Biol 34:130-139

Goudet J (2002) FSTAT version 2.9. 3.2: a program to estimate and test gene diversities and fixation indices. Institute of Ecology, Lausanne

Greenwald KR, Gibbs HL, Waite AT (2009) Efficacy of land-cover models in predicting isolation of marbled salamander populations in a fragmented landscape. Conserv Biol 25:1232-1241

Guillot G, Mortier F, Estoup A (2005) GENELAND: a computer package for landscape genetics. Mol Ecol Notes 5(3):712-715

Hedrick P (2005) Genetics of populations. Jones and Bartlett, Sudbury

Huey RB (1982) Temperature, physiology, and the ecology of reptiles. In: Gans C, Pough FH (eds) Biology of the reptilian (vol 12 Physiology C. Physiological Ecology, pp 25-91). Academic Press, New York

IUCN Red List of Threatened Species (2016) http://www.iucnredlist. org. 15th March 2015

Jehle R, Arntzen JW (2002) Microsatellite markers in amphibian conservation genetics. Herpetol J 12:1-9

Johnson JR, Johnson BB, Shaffer B (2010) Genotype and temperature affect locomotor performance in a tiger salamander hybrid swarm. Funct Ecol 24:1073-1080

Jost L (2008) GST and its relatives do not measure differentiation. Mol Ecol 17:4015-4026

Keller LF, Waller DM (2002) Inbreeding effects in wild populations. Tree 17:230-241

Lande R (1988) Genetics and demography in biological conservation. Science 241:1455-1460

Lemos-Espinal JA, Smith GR, Ruíz ÁH, Ayala RM (2016) Stream use and population characteristics of the endangered salamander, Ambystoma altamirani, from the Arroyo Los Axolotes, State of Mexico, Mexico. Southwest Nat 61(1):28-32

Marsh DM, Trenham PC (2001) Metapopulation dynamics and amphibian conservation. Conserv Biol 15(1):40-49

Mastretta-Yanes A, Quadri-Barba P, Escalante T, ArredondoAmezcua L, Piñero D (2014) Propuesta de cambios a la zonificación y modificaciones al Programa de Manejo del APFF
Nevado de Toluca tras reunión de discusión con CONANP en diciembre 2013. México

Matschiner M, Salzburger W (2009) TANDEM: integrating automated allele binning into genetics and genomics workflows. Bioinformatics 25:1982-1983

Monroy-Vilchis O, Zarco-González MM, Domínguez-Vega H, Sunny A (2015) Ambystoma leorae (Taylor, 1943): new records, natural history notes and threat status. Herpetozoa 27:166-168

Myers EM, Zamudio K (2004) Multiple paternity in an aggregate breeding amphibian: the effect of reproductive skew on estimates of male reproductive success. Mol Ecol 13:1951-1963

Naughton GP, Henderson CB, Foresman KR, McGraw RL (2000) Long-toed salamanders in harvested and intact Douglas-fir forests of western Montana. Ecol Appl 10:1681-1689

Nei M (1972) Genetic distance between populations. Am Nat 106:283-292

Nei M, Tajima F, Tateno Y (1983) Accuracy of estimated phylogenetic trees from molecular data. J Mol Evol 19(2):153-170

Noël S, Lapointe FJ (2010) Urban conservation genetics: study of a terrestrial salamander in the city. Biol Conserv 143:2823-2831

Palsbøll P, Berube M, Allendorf F (2007) Identification of management units using population genetic data. Trends Ecol Evol 22:11-16

Parra-Olea G, García-París M, Wake DB (1999) Status of some populations of Mexican salamanders (Amphibia: Plethodontidae). Rev Biol Trop 47:217-223

Parra-Olea G, Recuero E, Zamudio KR (2007) Primer note: polymorphic microsatellite markers for Mexican salamanders of the genus Ambystoma. Mol Ecol Notes 7:818-820

Parra-Olea G, Zamudio KR, Recuero E, Aguilar-Miguel X, Huacuz D, Zambrano L (2012) Conservation genetics of threatened Mexican axolotls (Ambystoma). Anim Conserv 15(1):61-72

Parra-Olea G, Flores-Villela O, Mendoza-Almeralla C (2014) Biodiversidad de anfibios en México. Rev Mex Biodivers 85:460-466

Pauly GB, Bennett SH, Palis JG, Shaffer HB (2012) Conservation and genetics of the frosted flatwoods salamander (Ambystoma cingulatum) on the Atlantic coastal plain. Conserv Genet 13(1):1-7

Peakall R, Smouse PE (2006) GENALEX 6: genetic analysis in Excel. Population genetic software for teaching and research. Mol Ecol Notes 6:288-295

Percino-Daniel R, Recuero E, Vázquez-Domínguez E, Zamudio KR, Parra-Olea G (2016) All grown-up and nowhere to go: paedomorphosis and local adaptation in Ambystoma salamanders in the Cuenca Oriental of México. Biol J Linn Soc 118(3):582-597

Piry S, Luikart G, Cornuet JM (1999) BOTTLENECK: a computer program for detecting recent reductions in the effective population size using allele frequency data. J Hered 90:502-503

Polich RL, Searcy CA, Shaffer HE (2013) Effects of tail clipping on survivorship and growth of larval salamanders. J Wildl Manag 77(7):1420-1425

Pritchard JK, Stephens M, Donnelly P (2000) Inference of population structure using multilocus genotype data. Genetics 155:945-959

Purrenhage JL, Niewiarowski PH, Moore FBG (2009) Population structure of spotted salamanders (Ambystoma maculatum) in a fragmented landscape. Mol Ecol 18:235-247

Queller DC, Goodnigh KF (1989) Estimating relatedness using genetic markers. Evolution 43:258-275

Raymond M, Rousset F (1995) GENEPOP v 12: population genetics software for exact test and ecumenicism. J Hered 86:248-249

Ribeiro R, Santos X, Sillero N, Carretero MA, Llorente GA (2009) Biodiversity and land uses at a regional scale: is agriculture the biggest threat for reptile assemblages? Acta Oecol 35:327334

Rueda Zozaya P, Mendoza-Martínez G, Martínez-Gómez D, MonroyVilchis O, Antonio-Godoy J, Sunny A, Palomares F, Chávez C, 
Herrera-Haro J (2016) Genetic variability and structure of jaguar (Panthera onca) in Mexican zoos. Genetica 144:59-69

Sarukhán J, Koleff P, Carabias J, Soberon J, Dirzo R (2009) Capital Natural de México. Síntesis Conocimiento actual, evaluación y perspectivas de la sustentabilidad. México: Comisión Nacional para el Uso y Conocimiento de la Biodiversidad

Savage WK, Fremier AK, Shaffer HB (2010) Landscape genetics of alpine Sierra Nevada salamanders reveals extreme population subdivision in space and time. Mol Ecol 19:3301-3314

Searcy CA, Shaffer HB (2008) Calculating biologically accurate mitigation credits: insights from the California tiger salamander. Conserv Biol 22:997-1005

SEMARNAT (2010) Norma Oficial Mexicana NOM-059- SEMARNAT-2010, Protección ambiental-Especies nativas de México de flora y fauna silvestres-Categorías de riesgo y especificaciones para su inclusión, exclusión o cambio-Lista de especies en riesgo. México: Diario Oficial de la Federación, 10 diciembre 2010

Semlitsch RD (2008) Differentiating migration and dispersal processes for pond-breeding amphibians. J Wildl Manag 72:260-267

Shaffer B, Huacaz D, Flores-Villela O, Parra-Olea G, Wake D, Papenfuss T (2008) Ambystoma rivulare. http://www.iucnredlist. org/details/59067/0. Accessed 17 Sept 2014

Spear S, Storfer A (2010) Anthropogenic and natural disturbance lead to differing patterns of gene flow in the Rocky Mountain tailed frog, Ascaphus montanus. Biol Conserv 143:778-786

Spear SF, Peterson CR, Matocq MD, Storfer A (2006) Molecular evidence for historical and recent population size reductions of tiger salamanders (Ambystoma tigrinum) in Yellowstone National Park. Conserv Genet 7(4):605-611

Storfer A, Eastman JM, Spear SF (2009) Modern molecular methods for amphibian conservation. Bioscience 59:559-571

Summitt SD (2009) Determination of dispersal patterns of the smallmouthed salamander (Ambystoma texanum) in Eagle Creek Park (Indianapolis, IN). B.Sc Thesis. Butler University

Sunny A, Monroy-Vilchis O, Fajardo V, Aguilera-Reyes U (2014a) Genetic diversity and structure of an endemic and critically endangered stream river salamander (Caudata: Ambystoma leorae) in Mexico. Conserv Genet 15:49-59

Sunny A, Monroy-Vilchis O, Reyna-Valencia C, Zarco-González MM (2014b) Microhabitat types promote the genetic structure of a micro-endemic and critically endangered mole salamander (Ambystoma leorae) of Central Mexico. PLoS ONE 9:e103595. doi:10.1371/journalpone0103595

Sunny A, Monroy-Vilchis O, Zarco-González MM, MendozaMartínez GD, Martínez-Gómez D (2015) Genetic diversity and genetic structure of an endemic Mexican Dusky Rattlesnake (Crotalus triseriatus) in a highly modified agricultural landscape: implications for conservation. Genetica 143:705-716

Tallmon DA, Funk WC, Dunlap WW, Allendorf FW (2000) Genetic differentiation among long-toed salamander (Ambystoma macrodactylum) populations. Copeia 2000:27-35

R Development Core Team (2013) R: a language and environment for statistical computing. R Foundation for Statistical Computing, Vienna. http://www.r-project.org. Accessed 15 Oct 2015
Tennessen JA, Zamudio KR (2003) Early-male reproductive advantage multiple paternity and sperm storage in an amphibian aggregate breeder. Mol Ecol 12:1567-1576

Trenham PC, Shaffer HB (2005) Amphibian upland habitat use and its consequences for population viability. Ecol Appl $15: 1158-1168$

Van Oosterhout C, Hutchinson WF, Wills DPM, Shipley P (2004) MICRO-CHECKER: software for identifying and correcting genotyping errors in microsatellite data. Mol Ecol Notes 4:535-538

Vázquez-Domínguez E, Surárez-Atilano M, Booth W, González-Baca C, Cuarón AD (2012) Genetic evidence of a recent successful colonization of introduced species on islands: Boa constrictor imperator on Cozumel Island. Biol Invasions 14:2101-2116

Vega R, Vázquez-Domínguez E, Mejía-Puente A, Cuarón AD (2007) Unexpected high levels of genetic variability and the population structure of an island endemic rodent (Oryzomys couesi cozumelae). Biol Conserv 137(2):210-222

Vidal O, López-García J, Rendón-Salinas E (2014) Trends in deforestation and forest degradation after a decade of monitoring in the Monarch Butterfly Biosphere Reserve in Mexico. Conserv Biol 28(1):177-186

Vucetich JA, Waite TA (2000) Is one migrant per generation sufficient for the genetic management of fluctuating populations? Anim Conserv 3(3):261-266

Waltert M, Mardiastuti A, Muhlenberg M (2004) Effects of land use on bird species richness in Sulawesi, Indonesia. Conserv Biol 18:1339-1346

Wang IJ (2009) Fine-scale population structure in a desert amphibian: landscape genetics of the black toad (Bufo exsul). Mol Ecol 18:3847-3856

Wang IJ, Summers K (2010) Genetic structure is correlated with phenotypic divergence rather than geographic isolation in the highly polymorphic strawberry poison-dart frog. Mol Ecol $19: 447-458$

Wang IJ, Savage WK, Shaffer HB (2009) Landscape genetics and least-cost path analysis reveal unexpected dispersal routes in the California tiger salamander (Ambystoma californiense). Mol Ecol 18:1365-1374

Weir BS, Cockerham CC (1984) Estimating F-statistics for the analysis of population structure. Evolution 38:1358-1370

White D, Minotti PG, Barczak MJ, Sifneos JC, Freemark KE, Santelmann MV, Steinitz CF, Kiester AR, Preston EM (1997) Assessing risks to biodiversity from future landscape change. Conserv Biol 11:349-360

WWF (2004) La tala ilegal y su impacto en la reserva de la biosfera Mariposa Monarca. World Wildlife Fund, México

Zambrano L, Valiente E, Vander Zanden MJ (2010) Food web overlap among native axolotl (Ambystoma mexicanum) and two exotic fishes: carp (Cyprinus carpio) and tilapia (Oreochromis niloticus) in Xochimilco, Mexico City. Biol Invasions 12(9):3061-3069 